\title{
PENGUKURAN KINERJA KOPERASI BERBASIS BALANCED SCORECARD
}

\author{
Novy Rachma Herawati \\ Alvian Viko Isnandi \\ Yulia Eka Sari
}

Fakultas Ekonomi Universitas Merdeka Madiun

novy@unmer-madiun.ac.id

\begin{abstract}
Village Unit Cooperative (KUD) serves as a service center for economic activities in rural areas and is an integral part of national development that has a significant role in the economy of the community. The purpose of this study is to know the performance of cooperatives in financial and nonfinancial in a balanced way so it can be known the development of strategy achievement by using Balanced Scorecard based measurement, by displaying four Perspective namely Financial Perspective, Customer Perspective, Internal Business Process Perspective and Learning and Growth Perspective. Return On Assets in Madurasa Village Unit Cooperative, in 2015 amounted to 0, 167\% and in 2016 amounted to 0, 204\%. This is changing where there is an increase of 0, 37\% indicating from the result of analysis indicate the ability of cooperative to produce profit increasing. While the Return On Equity Madurasa Village Unit Cooperative, in 2015 by $0.2 \%$ and in 2016 by $0.1 \%$, this result decreased by $0.1 \%$. This means that the smaller the value of ROE, the smaller the ability of the cooperative to generate net income for the owners of capital. The level of customer complaints in 2015 amounted to $0.02 \%$ while in 2016 by $0.03 \%$ in the presence of customer complaints increased by 0.01\%. the level of development of the type of products / services in 2015 amounted to $0.59 \%$ and in the year 2016 of $0.46 \%$ resulting in a decrease in the year 2016 of $0.13 \%$. The result of productivity level of employees of Madurasa Village Unit Cooperative in 2015 ranges from $R p$ 86,754,105 to decrease in 2016 around $R p$ 77,761,135 or 8,9\% decrease of employee productivity, this is because of decreasing of income amount in the form of interest from receivable
\end{abstract}

Keyword : Cooperative, Balanced Scorecard, Financial, Non Financial.

\section{PENDAHULUAN}

Kinerja merupakan hal yang sangat penting dalam suatu perusahaan. Hal ini dikarenakan kinerja adalah gambaran terkait dengan tingkat pencapaian pelaksanaan suatu kegiatan, program, dan juga kebijakan dalam mewujudkan tujuan atau sasaran dari perusahaan (Jariah, 2015). Pengukuran kinerja sangat penting bagi perusahaan untuk dapat bersaing di lingkungan yang sangat kompetitif. Kaplan dan Norton (2000) berpendapat, 
bahwa "perusahaan yang tidak bisa mengukur strategi yang akan dibuat maka perusahaan tidak akan dapat mengelola dan menjalankan strategi yang dibuat tersebut". Pengukuran kinerja suatu perusahaan tidak hanya terpaku pada ukuran hasil atau perspektif keuangan saja, tetapi juga pengukuran kinerja non-keuangan yang dilakukan. Penggambaran kinerja perusahaan secara keseluruhan dan berimbang tersebut dikenal dengan metode Balanced scorecard.

"Balanced Scorecard (BSC) merupakan alat yang digunakan untuk mengukur kinerja secara komprehensif yang mencerminkan ukuran-ukuran yang sangat penting untuk kesuksesan strategi perusahaan dan juga menyediakan sarana untuk pengukuran kinerja dengan strategi perusahaan" (Blocher et al, 2011). Penerapan metode Balanced scorecard dalam pengukuran kinerja perusahaan, diharapkan kinerja perusahaan dapat diukur secara keseluruhan dan berimbang, serta kinerja keuangan dapat meningkat.

"Balanced scorecard menilai kinerja suatu perusahaan dalam empat Perspektif yang berbeda yaitu: Perspektif Keuangan, Perspektif Pelanggan, Perspektif Proses Bisnis Internal, dan Perspektif Pembelajaran dan Pertumbuhan" (Kaplan dan Norton, 2000). Penelitian ini menggunakan koperasi sebagai obyek yang akan diteliti hal ini dikarenakan koperasi memiliki keistimewaan dibandingkan dengan perusahaan, karena koperasi dimiliki oleh anggota dan bukan milik perorangan secara pribadi. "Koperasi adalah badan usaha yang beranggotakan orang-seorang atau Badan Hukum Koperasi dengan melandaskan kegiatannya berdasarkan prinsip Koperasi sekaligus sebagai gerakan ekonomi rakyat yang berdasarkan atas asas kekeluargaan" (UU Republik Indonesia Nomor 25 Tahun 1992).

Tujuan dari pendirian koperasi adalah memajukan kesejahteraan para anggota pada khususnya dan juga masyarakat pada umumnya, selain itu juga turut membangun tatanan perekonomian nasional dalam rangka mewujudkan masyarakat maju, adil dan juga makmur. Terdapat berbagi macam jenis koperasi yang ada di Indonesia diantaranya adalah Koperasi Unit Desa (KUD). Penelitian ini menggunakan KUD "Madurasa" sebagai obyek penelitian dimana KUD "Madurasa" berdiri pada tahun 1975, tetapi sampai dengan tahun 2017 belum pernah dilakukan pengukuran kinerja hal ini dikarenakan SDM (Sumber Daya Manusia) yang dimiliki sangat minim atau terbatas dalam hal pengetahuan, sehingga perlu 
adanya alat atau media yang dapat dilakukan untuk mengukurnya, hal ini penting untuk menjaga agar KUD Madurasa dapat bertumbuh dengan baik.

\section{TUJUAN DAN MANFAAT}

Penelitian ini bertujuan untuk mengetahui kinerja Koperasi Unit Desa (KUD) Madurasa selama 1 (satu) tahun yaitu dari tahun 2015 sampai dengan tahun 2016 dengan menggunakan pengukuran kinerja baik secara financial dan nonfinancial atau menggunakan Balanced Scorecard. Manfaat yang diharapkan dari penelitian ini adalah:

a. Bagi peneliti terutama dalam menerapkan ilmu yang dipelajari. Bagi Koperasi khususnya Koperasi Unit Desa (KUD) sebagai masukan yang dapat dipertimbangkan untuk mengetahui kinerja KUD ditinjau dari Balanced Scorecard,

b. Mengidentifikasi berbagai pemborosan sekaligus mendorong upaya pengurangan terhadap pemborosan,

c. Membuat suatu tujuan strategis yang biasanya masih kurang baik atau tepat sasaran menjadi lebih nyata sehingga mempercepat proses pembelajaran organisasi. Hasil penelitian ini di harapkan bisa memberi kontribusi lebih luas berupa sebagi masukan dan pertimbangan kinerja KUD Madurasa.

\section{KAJIAN PUSTAKA}

\section{Pengukuran Kinerja}

Kinerja menurut Mulyadi dan Setiawan (2007) adalah 'keberhasilan suatu tim, personel ataupun organisasi dalam mewujudkan sasaran strategis yang telah ditetapkan sebelumnya dengan perilaku yang diharapkan”. Sementara itu kinerja merupakan hasil usaha ataupun prestasi yang dicapai dalam periode waktu tertentu. "Untuk memantau dan menelusuri kemajuan tujuan strategis diperlukan adanya pengukuran (measurement) kinerja" (Gaspersz, 2002). Pengukuran dapat berupa indikator yang memimpin kinerja menuju hasil akhir (lead indicator).

Penilaian kinerja digunakan untuk memastikan bahwa tim atau personel dalam suatu organisasi melakukan tugas dengan baik dalam mengimplementasikan strategi perusahaan atau organisasi. Pengukuran kinerja atau penilaian kinerja diharapkan dapat memotivasi 
personel dalam mencapai sasaran strategik organisasi dan dalam mematuhi standar perilaku yang telah ditetapkan sebelumnya, agar membuahkan tindakan dan juga hasil yang dikehendaki oleh suatu organisasi.

\section{Konsep Balanced Scorecard}

Balanced Scorecard (Yuwono, 2002) adalah "sistem manajemen, pengukuran dan juga pengendalian secara tepat, cepat dan komprehensif sehingga dapat memberikan pemahaman tentang suatu bisnis kepada manajer". Balanced adalah seimbang sementara itu Scorecard adalah kartu skor yang digunakan untuk mencatat skor kinerja suatu organisasi atau disebut juga skor individu. "Balanced Scorecard merupakan alat manajemen kontemporer yang digunakan untuk meningkatkan kemampuan organisasi yang digunakan untuk melipatgandakan kinerja keuangan sehingga penggunaan BSC dalam organisasi menjanjikan peningkatan signifikan dalam menciptakan kekayaan suatu perusahaan" (Mulyadi dan Setiawan, 2007)

"Balanced scorecard memungkinkan organisasi/perusahaan mencatat hasil kinerja finansial sekaligus memantau kemajuan organisasi/perusahaan dalam membangun kemampuan dan mendapatkan aktiva tak berwujud yang dibutuhkan untuk pertumbuhan masa mendatang" (Kaplan dan Norton, 2000). Balanced scorecard dapat digunakan untuk melengkapi seperangkat ukuran finansial kinerja masa lalu dengan ukuran pendorong (drivers) kinerja masa depan. Tujuan dan ukuran scorecard diturunkan dari visi dan strategi yang memandang kinerja organisasi/perusahaan dari empat perspektif: financial, pelanggan, proses bisnis internal, serta pembelajaran dan pertumbuhan. Adapun Keunggulan Balanced Scorecard menurut Mulyadi (2014) adalah sebagai berikut:

a. Komprehensif yaitu memandang perencanaan strategis dari perspektif keuangan, pelanggan, proses bisnis dan juga pembelajaran dan pertumbuhan,

b. Koheren, yaitu membangun hubungan sebab akibat (casual relationship) diantara berbagai sasaran strategik yang dihasilkan dalam perencanaan strategik,

c. Berimbang, yaitu memelihara keseimbangan antara sasaran strategis di empat perspektif sehingga perusahaan dapat memperoleh informasi yang menyeluruh.

\section{METODE PENELITIAN}




\section{Jenis Data}

Data adalah sekumpulan informasi yang diperlukan untuk pengambilan keputusan. Data yang digunakan dalam penelitian ini adalah data sekunder dan juga data primer. Data sekunder diperoleh dari data yang ada di Koperasi Unit Desa (KUD) Madurasa sedangkan Data Primer diperoleh dari wawancara langsung dengan pengelola KUD Madurasa yaitu manajer dan juga pengurus koperasi yang terdiri dari ketua, sekretaris dan bendahara.

\section{Alat Analisis}

Alat analisis yang digunakan dalam penelitian ini adalah aspek yang terkandung didalam Balanced Scorecard yaitu keuangan, pelanggan, proses bisnis internal, pembelajaran dan pertumbuhan dan skor perspektif kinerja dan skala kinerja. Alat analisis yang digunakan dalam penelitian ini adalah sebagai berikut:

\section{Perspektif Keuangan}

a. ROA (Return On Asset) yaitu kemampuan perusahaan untuk menghasilkan keuntungan atau laba bersih dari seluruh asset yang dimiliki.

Rumus ROA $=\frac{\text { Laba Bersih }}{\text { Total Aset }} \times 100 \%$

b. ROE (Return On Equity)

menunjukkan besarnya pendapatan bersih yang diperoleh perusahaan dari equity atau ekuitas yang dimilikinya.

Rumus ROE $=\frac{\text { Laba Bersih }}{\text { Total Ekuitas }} \times 100 \%$

\section{Perpektif Pelanggan/ Anggota}

Pelanggan dalam koperasi yang dimaksud adalah anggota dan juga masyarakat yang memanfaatkan jasa dari koperasi. Tolak ukurnya adalah sebagai berikut:

a. Kepuasan anggota, merupakan kemampuan koperasi dalam memenuhi kebutuhan anggota, terkait pelayanan yang diberikan, sehingga kepuasan anggota merupakan kepuasan yang dirasakan anggota terhadap seluruh kegiatan yang dilakukan oleh koperasi, merupakan nilai koperasi (Astuti, 2012). Persentase Keluhan $=\frac{\text { Jumlah Anggota }}{\text { Total Anggota }} \times 100 \%$ 
b. Retensi anggota, kemampuan koperasi dalam mempertahankan anggotanya. Semakin besar retensi anggota maka koperasi dianggap mampu mempertahankan anggota. Presentase Retensi $=\frac{\text { Jumlah Anggota Tetap }}{\text { Total Anggota }} \times 100 \%$

c. Akuisisi anggota (pelanggan), merupakan kemampuan koperasi dalam memperoleh anggota baru. Akuisisi anggota dapatdikatakan berhasil apabila memenuhi target yang telah ditentukansebelumnya maupun jumlah anggota terus meningkat setiap tahunnya.Pengukuran akuisisi anggota yaitu: Presentase Akuisisi $=\frac{\text { Jumlah Anggota Baru }}{\text { Jumlah Anggota } \text { Tahun Lalu }} \times 100 \%$

3. Perspektif Proses Bisnis Internal

Perspektif Proses Bisnis Internal ini meliputi Inovasi, Operasi dan Purna Jual. Adapun Tolok Ukurnya adalah sebagai berikut:

a. Perkembangan Produk Unggulan $=\frac{\text { Produk Unggulan } \text { Tahun Berjalan }}{\text { Produk Unggulan } \text { Tahun lalu }} \times 100 \%$

b. Aktiva Produktif yaitu aktiva koperasi yang mendatangkan keuntungan.

$$
\text { Aktiva Produktif }=\frac{\text { Pembiayaan }}{\text { Total Aktiva }} \times 100 \%
$$

c. Peningkatan sarana prasarana, merupakan kemampuan koperasi dalam meningkatkan pelayanan dengan memudahkan pemberian pelayanankepada anggota dan masyarakat. Peningkatan layanan dikatakan berhasilapabila dapat memenuhi target yang ditentukan serta mengalamipeningkatan setiap tahunnya.

4. Perspektif Pembelajaran dan Pertumbuhan

Untuk mengukur perpektif pembelajaran dan pertumbuhan dapat dilakukan dengan mengukur kemampuan karyawan dalam melaksanakan pekerjaan. Menurut Sony Yuwono, et all (2002) Rumus yang digunakan adalah :

Produktivitas Karyawan $=\frac{\text { Jumlah Karyawan }}{\text { Total Karyawan }} \times 100 \%$

\section{HASIL DAN PEMBAHASAN}

\section{A. Pengukuran Kinerja Perspektif Keuangan}

Pengukuran kinerja keuangan menunjukkan apakah perencanaan, implementasi dan pelaksanaan dari strategi memberikan keuntungan dari rasio keuangan KUD Madurasa 
dengan menggunakan metode pengukuran ROE (Rent On Equity) dan ROA (Rent On Asset).

\section{Pengukuran Rent On Asset (ROA)}

Return On Asset di Koperasi Unit Desa Madurasa,pada tahun 2015 sebesar 0, 167 \% dan di tahun 2016 sebesar 0, $204 \%$.Hal ini mengalami perubahan dimana terdapat penurunan $0,37 \%$ yang menandakan dari hasil analisis tersebut menunjukkan kemampuan koperasi menghasilkan laba semakin menurun.

\section{Pengukuran Rent On Equity (ROE)}

Return On Equity Koperasi Unit Desa Madurasa, pada tahun 2015 sebesar 0,2\% dan di tahun 2016 sebesar $0,1 \%$, hasil ini mengalami penurunan sebesar $0,1 \%$. Ini berarti Semakin kecil nilai ROE maka semakin kecil kemampuan koperasi menghasilkan pendapatan bersih bagi pemilik modal.

\section{B. Pengukuran Kinerja Perspektif Pelanggan}

Pengukuran kinerja pelanggan menunjukkan penilaian pelanggan terhadap pelayanan KUD Madurasa dalam memenuhi kebutuhan dan keinginan terhadap unitunit usaha yang ditawarkan.

\section{Pengukuran Tingkat Kepuasaan Pelanggan/Anggota}

Tingkat keluhan pelanggan pada tahun 2015 sebesar 0,02\% sedangkan pada tahun 2016 sebesar 0,03\% dengan adanya keluhan pelanggan yang meningkat sebesar 0,01\% . Hal ini menunjukan Kepuasan pelanggan yang menurun terhadap seluruh kegiatan yang dilakukan oleh koperasi.

\section{Pengukuran Tingkat Pertumbuhan Pelanggan/Anggota.}

Jumlah anggota yang menjadi pelanggan unit listrik mengalami penurunan sebanyak 390 orang, hal ini dikarenakan proses pembayaran listrik biasanya dilakukan di KUD tetapi di era sekarang perorangan sudah mampu melakukan bisnis pembayaran 
listrik sendiri sehingga pelanggan mengalami penurunan dan untuk jasa dan produk yang disediakan pada tahun 2016 sebanyak 6.099 orang, mengalami penurunan sebanyak 119 orang dibandingkan dengan tahun 2015,ini di karenakan pelanggan mulai berkurang minatnya terhadap produk/jasa yang di tawarkan oleh KUD Madurasa.

\section{Pengukuran Kinerja Perspektif Proses Bisnis Internal.}

Pengukuran kinerja dari perspektif proses bisnis internal pada KUD Madurasa dilakukan terhadap tingkat perkembangan jenis usaha yang dikelola oleh koperasi, baik perkembangan jenis usaha produk maupun jasa. Hal ini dilakukan untuk mengetahui apakah Koperasi mampu mengembangkan unit produk ataupun jasanya sesuai dengan kebutuhan pelanggan.

\section{Perhitungan tingkat perkembangan jenis Produk/Jasa}

Diketahui bahwa tingkat perkembangan jenis produk/jasa di tahun 2015 sebesar 0,59\% dan pada tahun 2016 sebesar 0,46 \% sehingga mengalami penurunan di tahun 2016 sebesar $0,13 \%$.

\section{Pengukuran Kinerja Perspektif Pembelajaran dan Pertumbuhan}

Pengukuruan produktivitas karyawan di ukur dengan jumlah pendapatan dan jumlah karyawan aktif sehingga menghasilkan rasio produktivitas karyawan.

\section{Perhitungan Produktivitas Karyawan}

Hasil tingkat produktivitas karyawan Koperasi Unit Desa Madurasa di tahun 2015 berkisar Rp 86.754.105 mengalami penurunan ditahun 2016 berkisar Rp 77.761.135 atau 8,9 \% menurunya produktivitas karyawan ,hal ini di karenakan menurunnya jumlah pendapatan berupa bunga dari piutang dikarenakan berkurangnya aktiva dalam hal ini kas untuk modal pemberian pinjaman, berkurangnya produktivitas berupa pendapatan ini menunjukkan kinerja di perspektif pembelajaran dan pertumbuhannya pun masih dapat dikatakan kurang baik.

\section{KESIMPULAN DAN SARAN}




\section{Kesimpulan}

1. Banyaknya enitas bisnis yang muncul seperti PPOB (Payment Point Online Bank) yang setiap individu sekarang ini mampu memiliki.

2. Banyak masyarakat yang mulai tidak tertarik untuk menjadi anggota koperasi karena adanya simpanan yang harus di bayar secara rutin setiap bulannya, selain itu dikarenakan akses terhadap perbankan sudah sangat mudah.

3. Kurangnya inovasi dan kreatifitas dari pengurus sehingga orang mulai tidak tertarik untuk bertransaksi di KUD (Koperasi Unit Desa). Hal ini disebabkan adanya image KUD yang ketinggalan zaman dan tidak berkembang.

\section{Saran yang di sampaikan :}

1. Pengurus harus memiliki inovasi untuk membuat KUD lebih di percaya orang atau masyarakat dengan cara menyediakan berbagai macam kebutuhan anggota, sehingga anggota merasa memiliki koperasi seperti penyediaan bahan kebutuhan sehari-hari atau UKM Mart, dll.

2. KUD harus berani bersaing dan berinovasi dengan enitas bisnis yang lain karena apabila tidak dilakukan maka dipastikan akan kalah bersaing. Hal yang dapat dilakukan diantaranya dapat menjalin kerjasama dengan entitas bisnis yang lain maupun menjalin kerjasama dengan pihak perbankan.

\section{DAFTAR PUSTAKA}

Blocher, Edward J. David E. Stout, \& Gary.C. 2011. Manajemen Biaya Penekanan Strategis. Jakarta: Salemba Empat.

Gaspersz, Vincent. 2002. Sistem Manajemen Terintegrasi Balanced Scorecard Dengan Six Sigma Untuk Organisasi Bisnis Dan Pemerintah. Jakarta : Gramedia Pustaka Utama.

Jariah, Ruliana \& Suyatin. 2015. Pengukuran Kinerja Pada Koperasi Semoga Jaya Unit Simpan Pinjam di Tenggarong.

Kaplan, R.S. \& Norton, D.P. 2000.Balanced Scorecard :Menerapkan Strategi Menjadi Aksi, diterjemahkan oleh Peter R. Yosi Pasla. Jakarta : Erlangga.

Mardiasmo.2002.Akuntansi Keuangan SektorPublik.Yogyakarta: Andi. 
Mulyadi \& Setiawan, J. 2007.Sistem Perencanaan Dan Pengendalian Manajemen: Sistem Pelipatgandaan Kinerja Perusahaan. Jakarta : Salemba Empat.

Prijambodo. 2015. Balanced Scorecard pada Koperasi. Diambil dari www.jurnal.smecda.com/index.php/infokop/article/download/62/59.

Yuwono Sony, Edy Sukamo,MuhammadIchsan.2002.Petunjuk PraktisPenyusunan Balanced Scorecard, cetakanpertama. Jakarta: PT.Gramedia PustakaUtama. 